\title{
Pertumbuhan dan Variasi Jumlah Kromosom Akar Rambut Morus macroura Miq. Hasil Transformasi dengan Beberapa Galur Agrobacterium
}

\author{
Growth and Variation in Chromosome Numbers of Morus macroura Miq. Hairy Root \\ Culture Transformed with Different Strains of Agrobacterium
}

\author{
Tri Muji Ermayanti* dan Dwi Hastuti
}

Pusat Penelitian Bioteknologi - LIPI, Jl. Raya Bogor Km 46 Cibinong 16911

E-mail: tmermayanti@hotmail.com *Penulis untuk korespondensi

\begin{abstract}
Morus macroura Miq. (Moraceae) which is native West Sumatra is now classified as endangered species and usually used as furniture. This plant produces phenolic compounds. Generally secondary metabolites produced by plants are found in low level, therefore, in vitro techniques such as callus culture, cell suspension and organ cultures are the alternative methods to increase their in vitro production. However, problems on genetic instability such as variation in chromosome numbers and abnormality of chromosome structure are found. These cases influence the productions of secondary metabolites. Genetic variation could be overcome using hairy root culture. The aim of the research was to analyze the growth and chromosome numbers of Morus macroura Miq. hairy root transformed with Agrobacterium strains TISTR-511, TISTR-512, ATCC-15834 and R-1000 in order to determine the genetic variation of the culture. Growth was determined by measuring the fresh and dry weights of roots after 4 weeks in culture. Chromosome numbers was prepared by squashing. The results showed that transformed roots had higher growth compared to the growth of untransformed roots. The growth of hairy roots was varied depending on the strains of Agrobacterium. Both transformed and untransformed roots had high variation in the chromosome numbers. Genetic stability of both transformed and untransformed roots were low but they had similar pattern of distribution on the chromosome number. The roots had the diploid number of chromosome $2 \mathrm{n}=2 \mathrm{x}=28$ ranged from 35.83 to $46.13 \%$ and the tetraploid numbers $2 n=4 x=56$ ranged from 23.23 to $42.21 \%$. Total cells examined were more that 230 cells.
\end{abstract}

Key words: Morus macroura, akar rambut, transformasi, Agrobacterium, pertumbuhan, jumlah kromosom

Diterima: 12 September 2008, disetujui: 25 Februari 2009

\section{Pendahuluan}

Morus macroura Miq. (famili Moraceae) merupakan tumbuhan asli habitus Sumatera Barat, yang oleh penduduk sekitar dikenal dengan nama Andalas. Habitus semak atau pohon, meranggas, bersifat monosius atau dioesius dan tinggi pohon dapat mencapai 30$60 \mathrm{~m}$ dengan diameter batang antara 150-224 cm (Sosef et al., 1998). Tanaman dari genus
Morus mempunyai jumlah kromosom dasar $\mathrm{x}=$ 14. Spesies Morus macroura memiliki jumlah kromosom diploid $2 \mathrm{n}=2 \mathrm{x}=28$ atau $2 \mathrm{n}=4 \mathrm{x}=$ 56 (Sosef et al., 1998). Populasi jenis ini semakin sedikit, dikarenakan tanaman ini belum banyak dibudidayakan sementara penduduk menebangnya untuk dimanfaatkan kayunya (Dahlan, 1995).

Menurut Sukanto et al., (2001), tanaman Morus mengandung beberapa jenis senyawa 
fenol yaitu senyawa turunan stilben misalnya oksiresveratrol dan dimer stilben yaitu andalasin A, turunan 2-arilbenzofuran misalnya morusin $\mathrm{B}$, mulberofuran $\mathrm{K}$ dan satu senyawa turunan kumarin, yakni 7-hidroksikumarin atau umbeliferon. Beberapa senyawa seperti oksiresveratrol, morusin, dan mulberofuran $\mathrm{K}$ menunjukkan aktivitas sitotoksik yang sangat tinggi terhadap sel tumor (Hakim et al., 2003). Senyawa umbeliferon bersifat antijamur dan antibakteri, juga sebagai fitoaleksin (Sukanto $e t$ al., 2001).

Senyawa metabolit sekunder mempunyai peranan sangat penting di berbagai bidang misalnya di bidang kedokteran, farmasi, industri makanan dan minuman, kosmetika serta industri pertanian (Soetjipto et al., 2007). Pada umumnya produk metabolit sekunder yang dihasilkan tanaman terdapat dalam jumlah kecil (Almahdy et al., 2006), oleh karena itu teknik kultur jaringan seperti kultur kalus, suspensi sel dan kultur organ dapat dijadikan metode alternatif dalam meningkatkan produksi metabolit sekunder secara in vitro dan dipergunakan untuk studi biosintesis dan biotransformasi (Hendaryono dan Wijayani, 1994). Namun, salah satu permasalahan dalam penggunaan teknik kultur kalus dan suspensi sel untuk produksi senyawa metabolit sekunder adalah ketidakstabilan genetik, seperti terjadi variasi jumlah kromosom dan abnormalitas pada struktur kromosom sehingga mempengaruhi produksi senyawa metabolit sekunder yang dihasilkan, mengurangi kemampuan regenerasi dan menyebabkan variasi fenotipe (Aird et al., 1988).

Variasi genetik dapat diatasi antara lain dengan menggunakan teknik Hairy Root Culture yaitu kultur akar hasil transformasi genetika dengan Agrobacterium rhizogenes (Flores dan Medina-Bolivar, 1995). Transformasi terjadi akibat integrasi DNA dari sel bakteri ke dalam sel tanaman, dalam hal ini plasmid Ri dari bakteri berintegrasi ke dalam genom tanaman yang menyebabkan tumbuhnya akar rambut (Baiza et al., 1999).

Pada beberapa jenis tanaman, kultur akar rambut lebih menguntungkan dibandingkan dengan kultur kalus atau suspensi sel, karena memiliki sifat genetik yang stabil dengan produksi metabolit sekunder yang tinggi, mudah ditumbuhkan pada media sederhana, tanpa penambahan zat pengatur tumbuh dan mempunyai frekuensi regenerasi tinggi (Baiza et al., 1999; Sudo et al., 2002). Kultur akar rambut pada beberapa tanaman mempunyai stabilitas genetika yang tinggi (Aird et al., 1988). Pada Catharantus roseus (Hamill et al., 1987), Nicotiana rustica (Aird et al., 1988), Swainsona galegifolia (Ermayanti et al., 1993) kultur akar rambut memiliki tingkat kestabilan genetik dan produksi metabolit sekunder yang lebih tinggi dibandingkan dengan kultur akar normal (bukan hasil transformasi dengan $A$. rhizogenes).

Tujuan penelitian ini adalah mengetahui respons pertumbuhan dan jumlah kromosom pada akar rambut Morus macroura hasil transformasi dengan A. rhizogenes galur TISTR-510, TISTR-511, ATCC-15834, dan A. tumefaciens galur R-1000. Selain itu, juga untuk mengetahui perbandingan distribusi kromosom akar rambut $M$. macroura hasil transformasi dengan akar nontransformasi.

\section{Metode Penelitian}

Bahan penelitian terdiri atas akar rambut Morus macroura yang berumur satu tahun (yang telah mengalami 4 kali subkultur) hasil transformasi dengan Agrobacterium rhizogenes galur TISTR-510 (galur A), TISTR-511 (galur B), ATCC-15834 (galur C), dan dengan Agrobacterium tumefaciens galur R-1000 (galur D). Akar ditumbuhkan pada media MS (Murashige dan Skoog, 1962) cair yang mengandung $1 \mathrm{mgl}^{-1}$ 2,4-D (Nurdiani et al., 2003). Baik akar rambut hasil transformasi maupun akar nontransformasi tidak dapat tumbuh pada media MS tanpa penambahan zat pengatur tumbuh, oleh karena itu penelitian ini menggunakan media MS yang mengandung 1 $\mathrm{mgl}^{-1}$ 2,4-D.

\section{Pertumbuhan akar}

Akar rambut hasil transformasi dengan bakteri galur A, B, C dan D sebanyak 0,5 g ditanam pada media cair sebanyak $20 \mathrm{ml}$. Akar nontransformasi (sebagai kontrol) dengan 3 kali ulangan Kultur diinkubasikan selama 4 minggu di dalam ruang kultur bersuhu $26-27^{\circ} \mathrm{C}$, 
di shaker dengan kecepatan $100 \mathrm{rpm}$ tanpa penyinaran. Setelah 4 minggu akar dipanen, berat basah dan berat keringnya ditimbang dengan cara mengeluarkan akar rambut dari botol kultur dan meletakkannya di atas kertas tisu terserap airnya. Setelah itu akar ditimbang untuk mengetahui berat basah. Untuk mendapatkan berat kering, akar yang telah ditimbang berat basahnya dikeringkan pada suhu ruang. Dari data berat basah dan berat kering kemudian dihitung indeks pertumbuhan relatif akar yaitu berat akar setelah berumur 4 minggu (pada saat panen) dikurangi dengan berat awal akar dibagi dengan berat awal akar. Pertambahan berat akar juga dihitung dengan cara mengurangi berat akhir dengan berat awal akar yang dikultur selama 4 minggu. Indeks pertumbuhan relatif dan pertumbuhan berat akar setelah 4 minggu menunjukkan pertumbuhan akar.

\section{Analisis jumlah kromosom}

Prosedur analisis kromosom yang digunakan mengikuti metode Karp (1991). Dari setiap kultur akar baik hasil transformasi maupun nontransformasi (akar kontrol) dari media cair yang telah memperlihatkan adanya cabang-cabang lateral yang berumur 3-4 minggu, dipilih akar yang berwarna putih bersih dan berukuran panjang sekitar $1 \mathrm{~cm}$. Akar yang terpilih kemudian direndam dalam larutan jenuh para-diklorobenzen (PDB) selama 4 jam dan disimpan pada suhu ruangan sekitar $30^{\circ} \mathrm{C}$ Setelah itu ujung akar dicuci 2 kali dengan akuades, kemudian dimasukkan ke dalam larutan fiksatif asam asetat dan etanol absolut (1:3), selama satu malam pada suhu $5^{\circ} \mathrm{C}$. Setelah itu akar dicuci 2 kali dengan akuades, dipindahkan ke dalam etanol $70 \%$ dan disimpan kembali pada suhu $5^{\circ} \mathrm{C}$ atau langsung diproses untuk pengamatan kromosom. Ujung akar dicuci dengan akuades, kemudian dilakukan hidrolisis dengan $\mathrm{HCl} 5 \mathrm{~N}$ selama 10 menit. Ujung akar kemudian dicuci kembali dengan akuades dilanjutkan dengan pewarnaan orsein $2 \%$ yang dilarutkan dalam larutan asam asetat $45 \%$ kurang lebih selama 4 jam pada suhu ruangan atau pada suhu $5^{\circ} \mathrm{C}$.

Pembuatan preparat dilakukan dengan menggunakan metode "squashing" (pencet) (Karp, 1991). Dipilih 2 ujung akar yang mempunyai sel-sel meristem yang sudah diwarnai, kaca objek yang telah ditetesi dengan asam asetat 45\%. Ujung akar yang telah dipotong (kira-kira 1-2 $\mathrm{mm}$ dari ujung akar) diletakkan pada kaca objek, kemudian ditutup dengan kaca penutup, ditekan dengan ibu jari, kelebihan asam asetat diserap dengan kertas tisu. Selanjutnya preparat dapat langsung diamati di bawah mikroskop.

Penghitungan jumlah kromosom dilakukan dengan menggunakan metode Ermayanti et al., (1993). Preparat diamati dan dihitung jumlah kromosomnya di bawah mikroskop dengan perbesaran 1000 kali. Penghitungan jumlah kromosom dilakukan pada 30 ujung akar untuk masing-masing galur akar.

\section{Hasil dan Pembahasan}

\section{Pertumbuhan akar}

Pada awal kultur, pertumbuhan akar rambut dari tanaman Morus macroura ini sangat lambat dan berwarna cokelat. Namun, setelah dilakukan 2-3 kali subkultur pertumbuhan akar mulai jelas dengan terlihatnya akar yang segar berwarna kuning dan secara visual terlihat ada pertambahan panjang.

Akar rambut hasil transformasi dengan ketiga galur $A$. rhizogenes (TISTR-510, TISTR-511, ATCC-15834) dan satu galur A. tumefaciens (R-1000) tumbuh dengan baik pada media MS yang mengandung $1 \mathrm{mgl}^{-1}$ 2,4-D. Pertumbuhan akar baru, untuk masingmasing kultur, mulai tampak sekitar 3 minggu setelah ditanam. Dari 4 klon akar rambut yang dikultur, akar rambut dari galur bakteri TISTR510 mempunyai pertumbuhan paling lambat dibandingkan dengan ke 3 klon akar rambut lainnya. Hal ini terlihat dari berat basah akar setelah 4 minggu, pertambahan berat dan indeks pertumbuhan relatif (Tabel 1). Akar rambut hasil transformasi dengan bakteri galur TISTR-510 juga mempunyai berat kering akhir dan pertambahan berat kering terkecil dibandingkan dengan akar rambut lainnya, namun tidak untuk indeks pertumbuhan relatifnya (Tabel 2). Perbedaan-perbedaan pertumbuhan pada setiap klon akar rambut 
tersebut kemungkinan berkaitan dengan perbedaan strain Agrobacterium yang digunakan untuk transformasi.

Berdasarkan berat basah akar, pertambahan berat dan indek pertumbuhan relatif tertinggi dicapai oleh akar rambut hasil transformasi dengan Agrobacterium galur ATCC-15834 yang berbeda nyata dengan akar kontrol (Tabel 2). Kecepatan pertumbuhan akar rambut kemungkinan berkaitan dengan proses penyerapan unsur-unsur hara yang terkandung di dalam media, dan fenotipe akar hasil transformasi.

Galur Agrobacterium rhizogenes sering diklasifikasi berdasar opin (agropin atau manopin) yang dikandungnya (Petit et al., 1983) Semua galur bakteri yang dipergunakan dalam penelitian ini merupakan tipe agropin. Tipe agropin biasanya memiliki TL dan TR-
DNA. TL-DNA diketahui membawa empat gen rol (A, B, C dan D) yaitu gen-gen yang bertanggungjawab terhadap terbentuknya akar rambut, sedangkan TR-DNA membawa gen iaa $\mathrm{M}$ dan iaa $\mathrm{N}$ yaitu gen-gen yang mengkode enzim-enzim yang terlibat dalam biosintesis auksin (Van Wordragen et al., 1992). Tanaman yang mengalami integrasi T-DNA dari bakteri mengekspresikan enzim baru yang mempengaruhi sintesis zat pengatur tumbuh auksin. Zat pengatur tumbuh tersebut diperlukan tanaman untuk meningkatkan sintesis protein dan memacu pertumbuhan akar primordia sehingga dapat meningkatkan pertumbuhan akar rambut. Hal ini kemungkinan terjadi pada akar rambut yang memiliki pertumbuhan akar yang lebih tinggi dibandingkan dengan akar kontrol.

Tabel 1. Rata-rata berat akhir, pertambahan berat basah dan indeks pertumbuhan relatif akar rambut Morus macroura Miq. setelah umur 4 minggu pada media MS cair yang mengandung 1 mg/l 2,4-D.

\begin{tabular}{cccccc}
\hline \hline Asal akar & Galur bakteri & $\begin{array}{c}\text { Berat awal } \\
(\mathbf{g})\end{array}$ & $\begin{array}{c}\text { Berat akhir } \\
(\mathbf{g}) \pm \text { SD }\end{array}$ & $\begin{array}{c}\text { Pertambahan } \\
\text { berat }(\mathbf{g}) \pm \text { SD }\end{array}$ & $\begin{array}{c}\text { Indeks pertumbuhan } \\
\text { relatif } \pm \text { SD }\end{array}$ \\
\hline \hline Non & & & & & \\
transformasi & - & 0,5 & $1,26 \pm 0,072 \mathrm{a}$ & $0,76 \pm 0,072 \mathrm{a}$ & $1,53 \pm 0,145 \mathrm{a}$ \\
& TISTR-510 (A) & 0,5 & $1,24 \pm 0,147 \mathrm{a}$ & $0,74 \pm 0,147 \mathrm{a}$ & $1,49 \pm 0,295 \mathrm{a}$ \\
& TISTR-511 (B) & 0,5 & $1,84 \pm 0,096 \mathrm{~b}$ & $1,34 \pm 0,096 \mathrm{~b}$ & $2,69 \pm 0,192 \mathrm{~b}$ \\
Transformasi & ATCC-15834 (C) & 0,5 & $1,83 \pm 0,006 \mathrm{~b}$ & $1,33 \pm 0,006 \mathrm{~b}$ & $2,67 \pm 0,012 \mathrm{~b}$ \\
& R-1000 (D) & 0,5 & $1,74 \pm 0,199 \mathrm{~b}$ & $1,24 \pm 0,199 \mathrm{~b}$ & $2,47 \pm 0,397 \mathrm{~b}$ \\
\hline \hline
\end{tabular}

Keterangan: Huruf yang berbeda pada masing-masing kolom menunjukkan perbedaan yang sangat nyata pada $\mathrm{P}<0,01$ menurut Uji Duncan's Multiple Range.

Tabel 2. Rata-rata berat akhir, pertambahan berat kering dan indeks pertumbuhan relatif akar rambut Morus macroura Miq. setelah umur 4 minggu pada media MS cair yang mengandung $1 \mathrm{mg} / 1$ 2,4-D.

\begin{tabular}{cccccc}
\hline \hline Asal akar & Galur bakteri & $\begin{array}{c}\text { Berat awal } \\
(\mathbf{g})\end{array}$ & $\begin{array}{c}\text { Berat akhir } \\
(\mathbf{g}) \pm \text { SD }\end{array}$ & $\begin{array}{c}\text { Pertambahan } \\
\text { berat }(\mathbf{g}) \pm \text { SD }\end{array}$ & $\begin{array}{c}\text { Indeks Pertumbuhan } \\
\text { relatif } \pm \text { SD }\end{array}$ \\
\hline \hline Non & & & & & \\
transformasi & - & 0,04 & $0,15 \pm 0,015 \mathrm{a}$ & $0,11 \pm 0,015 \mathrm{a}$ & $2,83 \pm 0,382 \mathrm{a}$ \\
& TISTR-510 (A) & 0,03 & $0,14 \pm 0,015 \mathrm{a}$ & $0,11 \pm 0,015 \mathrm{a}$ & $3,78 \pm 0,508 \mathrm{ab}$ \\
Transformasi & TISTR-511 (B) & 0,04 & $0,18 \pm 0,025 \mathrm{ab}$ & $0,14 \pm 0,025 \mathrm{ab}$ & $3,58 \pm 0,629 \mathrm{ab}$ \\
& ATCC-15834 (C) & 0,03 & $0,18 \pm 0,010 \mathrm{~b}$ & $0,15 \pm 0,010 \mathrm{~b}$ & $5,00 \pm 0,330 \mathrm{~b}$ \\
& R-1000 (D) & 0,04 & $0,17 \pm 0,015 \mathrm{ab}$ & $0,13 \pm 0,015 \mathrm{ab}$ & $3,17 \pm 0,382 \mathrm{ab}$ \\
\hline \hline
\end{tabular}

Keterangan: Huruf yang berbeda pada masing-masing kolom menunjukkan perbedaan yang sangat nyata pada $\mathrm{P}<0,01$ menurut Uji Duncan's Multiple Range. 
Pertumbuhan akar rambut Artemisia cina ex Poljakov hasil transformasi dengan $A$. rhizogenes galur A4, ATCC-15834 dan 0720001 tumbuh dengan baik pada media MS cair dengan penambahan 2,4-D. Berat basah dan berat kering akar setelah 4 minggu pada media MS cair lebih besar dibandingkan dengan akar kontrol. Hal ini kemungkinan ada hubungan dengan fenotipe akar rambut. Akar rambut 07-20001 mempunyai bulu akar dan cabang-cabang lateral lebih banyak dan tumbuh lebih cepat dibandingkan dengan akar rambut dari galur yang lainnya. Adanya bulu-bulu akar inilah yang kemungkinan menyebabkan penyerapan unsur-unsur hara dan air dari media ke dalam akar menjadi luas, sehingga akar tumbuh dengan cepat dan meningkatkan biomassa akarnya (Aryanti, 2001). Pengamatan fenotipe akar rambut Morus macroura perlu dilakukan untuk dapat memberikan informasi yang lengkap tentang hubungan antara pertumbuhan dengan fenotipenya.

Menurut Rhodes et al., (1994) dan Subroto et al., (2000) kultur akar rambut pada beberapa jenis tanaman memiliki pertumbuhan yang rendah, hal itu tergantung pada galur bakteri yang menginfeksi, sehingga untuk memacu pertumbuhan diperlukan penambahan zat pengatur tumbuh seperti 2,4-D, NAA, IAA. Misal pada Swainsona galegifolia (Ermayanti, 1993), Artemisia annua (Ermayanti, 2003) memerlukan tambahan IBA untuk meningkatkan pertumbuhan akar rambut. Hal ini terjadi pula pada tanaman Morus macroura Miq. Pada penelitian pendahuluan pertumbuhan akar rambut $M$. macroura, pertumbuhan terbaik pada media MS yang mengandung $1 \mathrm{mg} / 1$ 2,4-D.

\section{Penyebaran jumlah kromosom}

Hasil penghitungan jumlah kromosom pada Tabel 3 menunjukkan bahwa akar rambut Morus macroura mempunyai jumlah kromosom yang unik yaitu dari kisaran jumlah haploidnya $(n=14)$ hingga tetraploid $(4 n=56)$ untuk akar rambut hasil transformasi dengan bakteri galur TISTR-510, TISTR-511 dan R1000 , antara $2 \mathrm{n}=18$ hingga $4 \mathrm{n}=56$ untuk klon akar hasil transformasi dengan bakteri galur ATCC-15834, namun persentase distribusi kromosomnya tidak sama. Akar kontrol mempunyai kisaran jumlah kromosom yang sama dengan klon akar rambut hasil transformasi dengan bakteri galur ATCC15834, juga dengan persentase distribusi kromosom yang tidak sama.

Keunikan jumlah kromosom pada kultur akar Morus macroura ini juga dapat dilihat dari banyaknya sel yang mempunyai jumlah kromosom $2 \mathrm{n}=2 \mathrm{x}=28$ dan $2 \mathrm{n}=4 \mathrm{x}=56$ seperti tertera pada Gambar 1-5. Frekuensi munculnya kedua jumlah kromosom ini sangat signifikan, baik untuk akar rambut hasil transformasi dengan beberapa galur Agrobacterium maupun untuk akar kontrol.

Tabel 3. Distribusi kromosom pada kultur akar Morus macroura hasil transformasi beberapa galur Agrobacterium dan akar non transformasi.

\begin{tabular}{|c|c|c|c|c|c|c|c|}
\hline \multirow[t]{2}{*}{ Asal akar } & \multirow{2}{*}{$\begin{array}{c}\text { Galur } \\
\text { Agrobacterium }\end{array}$} & \multicolumn{4}{|c|}{ Sel dengan jumlah kromosom $(2 n=)$} & \multirow{2}{*}{$\begin{array}{c}\text { Kisaran Jumlah } \\
\text { Kromosom }\end{array}$} & \multirow{2}{*}{$\begin{array}{c}\text { Total sel } \\
\text { yang diamati }\end{array}$} \\
\hline & & $\begin{array}{c}14-27 \\
(\%)\end{array}$ & $\begin{array}{c}28 \\
(\%)\end{array}$ & $\begin{array}{c}29-55 \\
(\%)\end{array}$ & $\begin{array}{l}56 \\
(\%)\end{array}$ & & \\
\hline \multirow{4}{*}{ Transformasi } & TISTR-510 (A) & $\begin{array}{c}10 \\
(3,15) \\
19\end{array}$ & $\begin{array}{c}129 \\
(40,69) \\
137\end{array}$ & $\begin{array}{c}89 \\
(28,08) \\
72\end{array}$ & $\begin{array}{c}89 \\
(28,08) \\
69\end{array}$ & $14-56$ & 317 \\
\hline & TISTR-511 (B) & $\begin{array}{c}(6,40) \\
13\end{array}$ & $\begin{array}{c}(46,13) \\
102\end{array}$ & $\begin{array}{c}(24,24) \\
24\end{array}$ & $\begin{array}{c}(23,23) \\
93\end{array}$ & $14-56$ & 297 \\
\hline & ATCC-15834 (C) & $\begin{array}{c}(5,60) \\
10\end{array}$ & $\begin{array}{c}(43,97) \\
178\end{array}$ & $\begin{array}{c}(10,34) \\
79\end{array}$ & $\begin{array}{c}(40,09) \\
195\end{array}$ & $18-56$ & 232 \\
\hline & R-1000 (D) & $\begin{array}{c}(2,16) \\
22\end{array}$ & $\begin{array}{c}(38,53) \\
86\end{array}$ & $\begin{array}{c}(17,10) \\
52\end{array}$ & $\begin{array}{c}(42,21) \\
80\end{array}$ & $14-56$ & 462 \\
\hline transformasi & - & $(9,17)$ & $(35,83)$ & $(21,67)$ & $(33,33)$ & $18-56$ & 240 \\
\hline
\end{tabular}




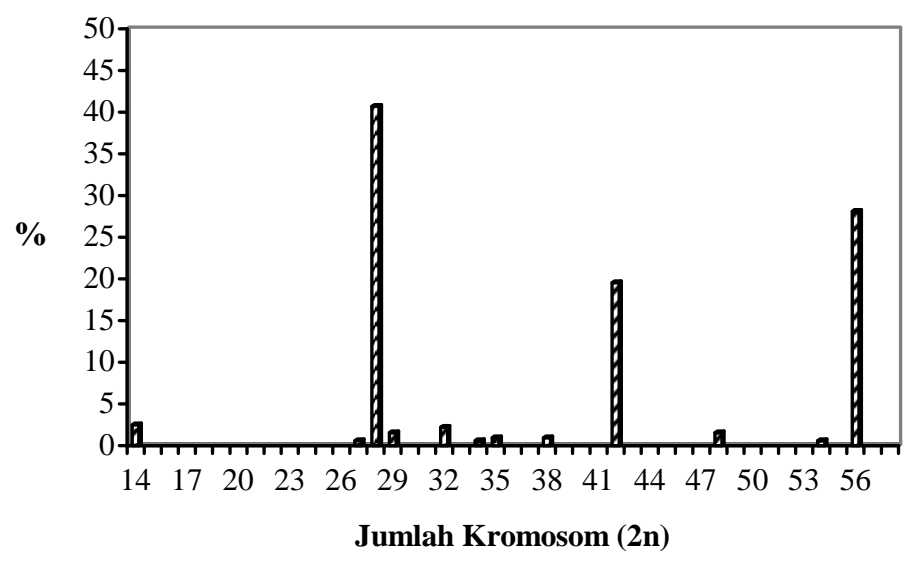

Gambar 1. Persentase variasi jumlah kromosom pada akar rambut Morus macroura Miq. galur TISTR-510.

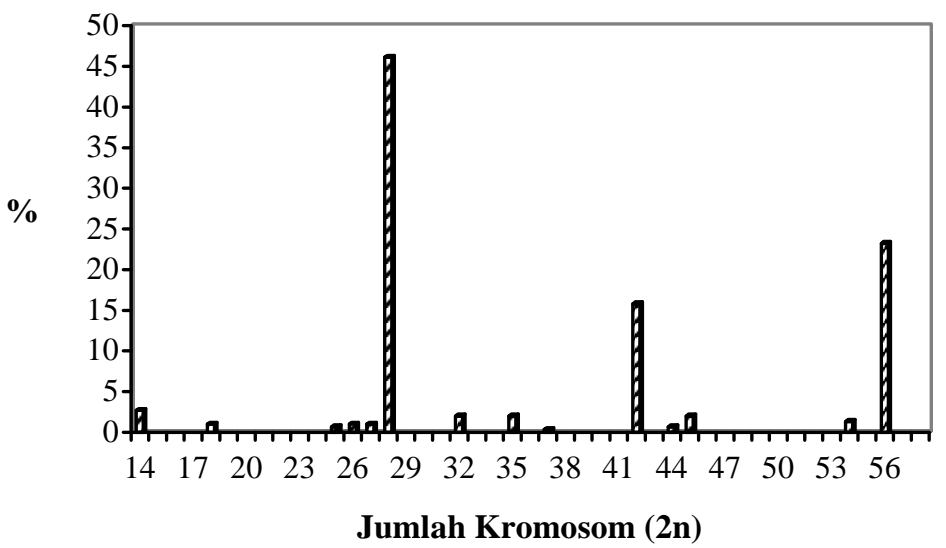

Gambar 2. Persentase variasi jumlah kromosom pada akar rambut Morus macroura Miq. galur TISTR-511.

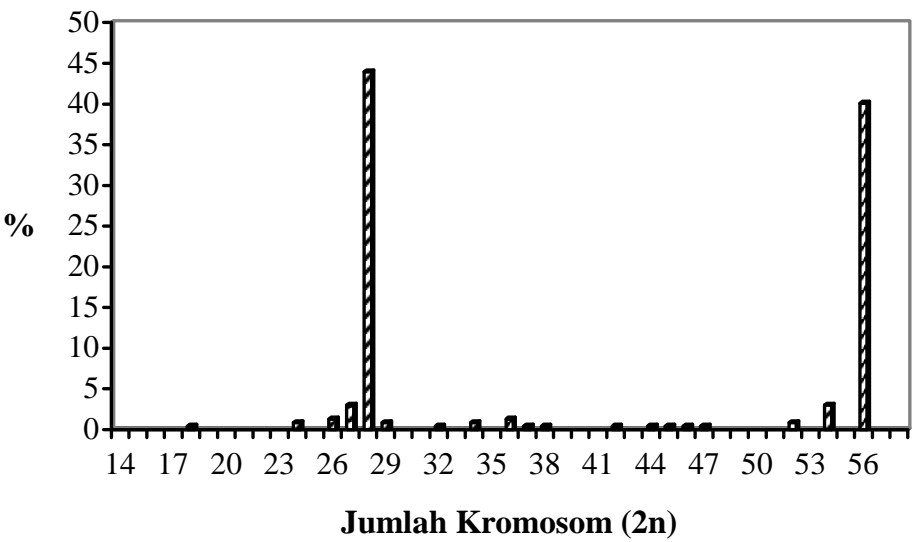

Gambar 3. Persentase variasi jumlah kromosom pada akar rambut Morus macroura Miq. galur ATCC-15834. 
Dari Tabel 3 dan Gambar 1-5 dapat dilihat bahwa sel yang mempunyai kromosom diploid $(2 \mathrm{n}=28)$ dari kultur akar rambut Morus macroura untuk masing-masing galur di bawah 50\%. Jumlah kromosom diploid pada akar rambut dan akar kontrol ini berkisar antara 35,83-46,13\%, sedangkan jumlah kromosom yang tetraploid berkisar antara 23,23-42,21\%. Jumlah kromosom diploid $(2 \mathrm{n}=28)$ yang tertinggi dicapai oleh akar rambut hasil transformasi dengan Agrobacterium galur TISTR-511 dan terendah oleh galur R-1000.
Sebaliknya jumlah kromosom tetraploid yang tertinggi $(2 \mathrm{n}=56)$ dicapai oleh galur R-1000 dan terendah oleh TISTR-511. Akar rambut dari galur R-1000 (Gambar 1) mempunyai persentase jumlah kromosom tetraploid lebih tinggi (42,21\%) dibandingkan sel yang mempunyai jumlah kromosom diploid $(38,53 \%)$. Berbeda dengan ke-tiga klon akar rambut lainnya (TISTR-510, TISTR-511, ATCC-15834) dan akar kontrolnya, jumlah kromosom diploidnya lebih tinggi dibandingkan kromosom tetraploid.

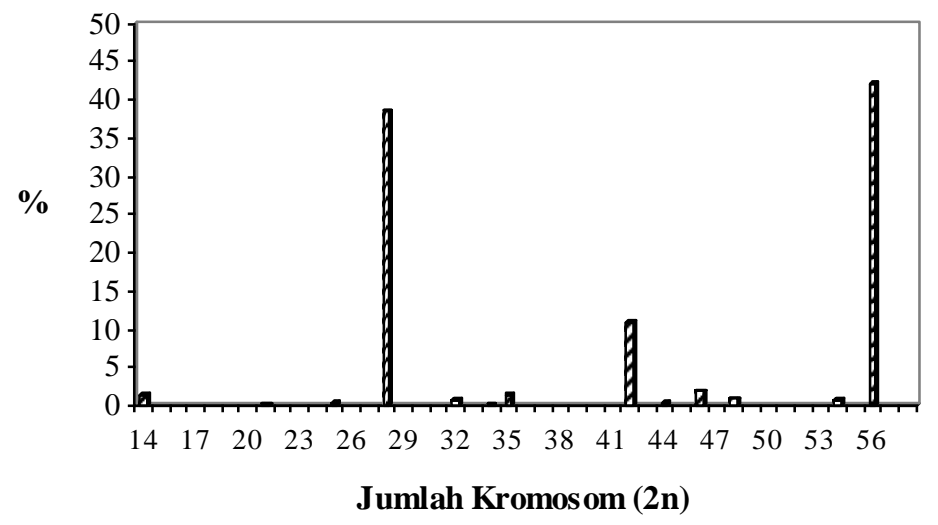

Gambar 4. Persentase variasi jumlah kromosom pada akar rambut Morus macroura Miq. galur R-1000.

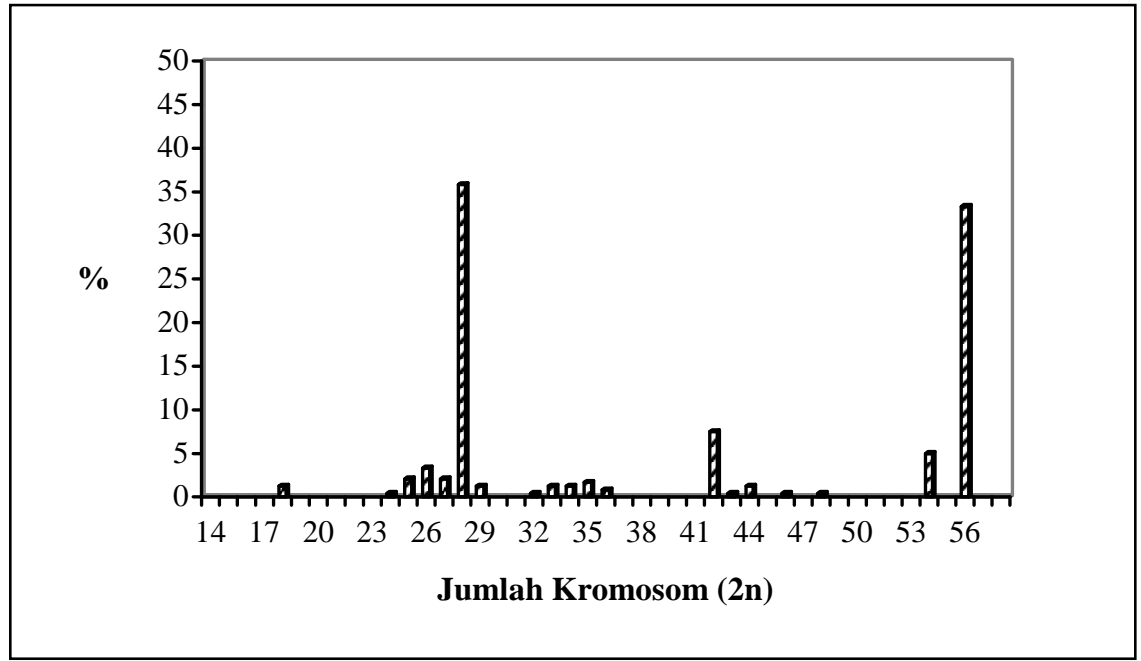

Gambar 5. Persentase variasi jumlah kromosom pada akar kontrol Morus macroura Miq. 
Tingkat kestabilan yang masih rendah pada jumlah kromosom diploid akar rambut Morus macroura ini serupa dengan akar rambut tanaman Vicia faba, di mana sel-selnya memiliki jumlah kromosom diploid sebanyak $50 \%$, sel poliploid $45 \%$ dan sel miksoploid sebanyak 5\% (Ramsay dan Kumar, 1990). Hal serupa juga terjadi pada tanaman Onobrychis viciaefolia yang mengalami reduksi jumlah kromosom dengan bertambahnya umur kultur dan subkultur (Xu dan Jia, 1996). Beberapa hasil penelitian melaporkan galur bakteri yang berbeda memberikan pengaruh yang berbedabeda pula terhadap pertumbuhan akar rambut, tergantung dari jenis tanaman yang ditransformasi. Subkultur berkali-kali hingga kultur berumur 17 bulan pada Nicotiana rustica hasil transformasi galur LBA 9402 tidak mempengaruhi stabilitas jumlah kromosomnya (Aird et al., 1988). Artemisia annua hasil transformasi dengan Agrobacterium rhizogenes galur LBA 9402 tetap memiliki jumlah kromosom diploid $2 \mathrm{n}=18$, sama dengan induknya walau telah berumur 20 bulan (Mukherjee et al., 1994). Pada akar rambut dari tanaman Onobrychis viciaefolia hasil transformasi dengan galur A4, 80\% sel-selnya mengalami haploidisasi setelah berumur 12 bulan. Pada penelitian ini, sel-sel pada ujung akar rambut Morus macroura galur R-1000 mengalami diploidisasi (38,53\%) sedangkan sel-sel yang aneuploid sebanyak $(61,47 \%)$. Dari contoh-contoh di atas memperlihatkan bahwa setiap galur bakteri yang dipergunakan memberikan pengaruh yang berbeda-beda tergantung dari jenis tanamannya.

Berdasarkan hasil penelitian ditemukan ada variasi jumlah kromosom pada kultur akar rambut Morus macroura dari setiap galur bakteri yang menginfeksinya. Variasi kromosom ini kemungkinan berkaitan dengan jumlah subkultur yang dilakukan. Semua akar rambut dan akar kontrol $M$. macroura pada penelitian ini telah mengalami empat kali subkultur. Semakin sering dilakukan subkultur kemungkinan terjadinya penyimpangan jumlah kromosom semakin besar (Towers dan Ellis, 1993). Selain frekuensi subkultur, umur kultur kemungkinan memberi pengaruh terhadap semakin luasnya penyimpangan jumlah kromosom. Umur kultur yang bertambah juga dapat menyebabkan daya totipotensi sel menjadi berkurang karena sel-sel mengalami penuaan (Hendaryono dan Wijayani, 1994). Subkultur berulang-ulang juga dapat meningkatkan variasi jumlah kromosom. Variasi ini dapat terjadi akibat aberasi kromosom baik pada jumlah maupun struktur yang diturunkan ke se-sel anakan (Bhojwani dan Razdan, 1983). Sebagai contoh pada kultur akar rambut Onobrychis viciaefolia hasil transformasi dengan Agrobacterium galur A4, di mana sel-selnya mengalami reduksi jumlah kromosom dan kehilangan kemampuan regenerasi seiring dengan bertambah umur kultur dan subkultur (Xu dan Jia, 1996).

Tabel 3 juga memperlihatkan bahwa selsel akar rambut dari ke-empat galur Agrobacterium dan akar kontrol mengalami perbedaan jumlah kromosom ke arah haploid, aneuploid dan poliploid. Hal ini disebabkan oleh proses aberasi kromosom dan kegagalan dalam pembelahan mitosis yang terjadi (Welsh dan Mogea, 1991; Suryo, 1995). Peristiwaperistiwa ini kemungkinan juga terjadi pada kultur akar Morus macroura sehingga mengakibatkan sebagian sel memiliki jumlah kromosom haploid, aneuploid dan poliploid. Haploidisasi pada kultur rambut Morus macroura kemungkinan juga dapat disebabkan oleh terjadinya penyimpangan dalam proses amitosis (pembagian inti menjadi dua bagian yang memiliki kandungan DNA tidak sama). Selain pada $M$. macroura, haploidisasi juga pernah terjadi pada kultur akar rambut Phaseolus coccineus, Allium sativum (D’Amato, 1990) dan Onobrychis viciaefolia (Xu dan Jia, 1996). Aneuploidi yang terjadi dapat diakibatkan oleh peristiwa amitosis, gagalnya duplikasi kromosom dan non disjuction (kromosom mengalami gagal memisah) pada saat anafase sehingga menyebabkan sel-sel anakannya mengalami penambahan atau pengurangan jumlah kromosom (Bayliss, 1980). Hal ini terjadi pada tanaman Daucus carota dan Nicotiana tabacum (D'amato, 1985). Hal serupa kemungkinan juga terjadi pada kultur akar Morus macroura Miq.

Akar rambut dari keempat galur Agrobacterium yang digunakan dan akar kontrol, mempunyai variasi jumlah sel-sel dengan kromosom diploid dan poliploid. 
Poliploid dapat terjadi apabila sel-sel yang mengandung jumlah genom berlebihan dari yang semestinya yaitu lebih tinggi dari yang normal 2n (diploid). Sel-sel yang diploid (normal 2n) pada saat mitosis mempunyai kromosom yang tetap berada di tengah-tengah sel sehingga tidak mengalami pembelahan inti sel. Peristiwa ini disebut pula dengan endomitosis. Sel-sel diploid, juga dapat menjadi triploid (3n) atau tetraploid (4n) yang terjadi karena kromosom-kromosom tersebut tetap berada di tengah-tengah sel sehingga tidak mengikuti pembelahan intinya dengan demikian inti sel yang semula terdapat $2 \mathrm{n}$ kromosom (diploid) menjadi 3n, 4n kromosom (Sutrian, 1992). Poliploidi kemungkinan juga dapat disebabkan oleh kegagalan pada saat pembentukan gelendong sehingga mengakibatkan kromatid tidak dapat memisah, dengan demikian pembelahan sel tidak terjadi. Hal ini menyebabkan sel-selnya mengalami endoreduplikasi (D'Amato, 1990; Suryo, 1998). Fusi spindel juga dapat menyebabkan terjadinya poliploidi, hal ini dapat terjadi pada sel-sel binukleat sehingga terdapat 2 inti yang memasuki fase mitosis secara bersamaan (D’Amato, 1990).

Perubahan jumlah ploidi pada tanaman Morus macroura ini, serupa dengan kultur akar rambut Solanum tuberosum (de VriesUijtewaal et al., 1988). Variasi jumlah kromosom yang terjadi pada kultur akar Morus macroura ini mungkin juga dapat disebabkan oleh adanya integrasi T-DNA dari plasmid Ri yang bersifat acak pada genom tanaman, namun untuk membuktikannya diperlukan pengamatan lebih lanjut. Beberapa garamgaram mineral seperti Molibdat dan Boron yang terkandung dalam media kemungkinan juga dapat bersifat mutagenik, sehingga menyebabkan perubahan-perubahan pada susunan DNA yang terjadinya variasi jumlah kromosom (Cowder, 1993; Prawitasari et al., 2005). Adanya penambahan zat pengatur tumbuh 2,4-D pada kultur akar $M$. macroura kemungkinan dapat juga mempengaruhi adanya variasi jumlah kromosom pada kultur akar rambutnya. Zat pengatur tumbuh sintetik seperti 2,4-D dimungkinkan dapat menginduksi terjadinya perubahan jumlah kromosom pada kultur (Hendaryono dan Wijayani, 1994).
Diduga zat pengatur tumbuh 2,4-D merupakan faktor yang menyebabkan terjadinya aberasi kromosom. Seperti yang terjadi pada kultur suspensi sel Daucus carota, dimana penambahan zat pengatur tumbuh 2,4-D menyebabkan terjadinya multipolar anafase dan non disjunction, sehingga menyebabkan terbentuknya sel-sel aneuploid (Bayliss, 1980). Sedangkan menurut Bhojwani dan Razdan, 1983; penambahan 2,4-D, NAA, dan IAA pada media kultur Helianthus annus dapat menginduksi pembentukan sel-sel poliploid. Variasi jumlah kromosom pada kultur akar rambut Morus macroura Miq. ini kemungkinan juga dapat disebabkan oleh penambahan zat pengatur tumbuh 2,4-D pada media yang digunakan.

Variasi jumlah kromosom yang terjadi di alam biasanya dipengaruhi oleh faktor lingkungan, seperti nutrisi, suhu, air, kelembaban, dan pengaruh zat-zat kimia. Variasi lingkungan ini sifatnya tidak konstan (Yatim, 1972; Jusuf, 2001). Genus Morus, memiliki kromosom dasar $\mathrm{x}=14$. Beberapa spesies ada yang memiliki kromosom diploid $2 \mathrm{n}=2 \mathrm{x}=28$, misalnya Morus indica, Morus bombycis, Morus rubra, Morus nigra (Darlington dan Wylie, 1945), sedangkan Morus macroura memiliki kromosom unik yaitu $2 \mathrm{n}=2 \mathrm{x}=28$, dan $2 \mathrm{n}=4 \mathrm{x}=56$ (Sosef et al., 1998), Morus cathayana mempunyai jumlah kromosom $2 \mathrm{n}=4 \mathrm{x}=58$ atau $2 \mathrm{n}=8 \mathrm{x}=112$ (Darlington dan Wylie, 1945). Perbedaan jumlah kromosom ini kemungkinan diakibatkan oleh pengaruh suhu pada lingkungan tumbuh yang berbeda, (Sutrian, 1992). Jumlah kromosom yang unik pada Morus macroura yaitu $2 \mathrm{n}=2 \mathrm{x}=28$, atau $2 n=4 x=56$ kemungkinan disebabkan ada peristiwa pindah silang antara spesies-spesies yang telah ada, sehingga sel-selnya memiliki jumlah kromosom berbeda yaitu $2 \mathrm{n}=2 \mathrm{x}=28$ dan $2 n=4 x=56$.

\section{Kesimpulan}

Pertumbuhan akar rambut Morus macroura pada media MS yang mengandung 1 $\mathrm{mgl}^{-1}$ 2,4-D dipengaruhi oleh galur bakteri yang digunakan untuk transformasi. Berat basah akhir dan indek pertumbuhan dari kultur akar 
rambut hasil transformasi lebih tinggi dibandingkan dengan akar kontrol. Jumlah kromosom semua kultur akar rambut hasil transformasi dan akar kontrol menunjukkan tingkat variasi yang cukup tinggi dan tingkat kestabilan genetik semua galur bakteri yang digunakan (ATCC-15834, TISTR-510, TISTR511, R-1000) dan akar kontrol masih rendah, tetapi mempunyai pola penyebaran jumlah kromosom yang serupa.

\section{Ucapan Terima Kasih}

Ucapan terima kasih disampaikan kepada Dr. Prasetyorini dari Universitas Pakuan, Bogor yang telah memberikan masukan yang sangat berharga selama penelitian dan penulisan ini. Ucapan terima kasih juga disampaikan kepada Dyah Retno Wulandari SSi, MSi dan Erwin Al Hafiizh STP yang telah membantu persiapan analisis kromosom dan kultur akar.

\section{Daftar Pustaka}

Aird, E.L.H., Hamill, J.D. and Rhodes, M.J.C. 1988. Cytogenetic Analysis of Hairy Root Culture from a Number of Plant Species Transformed by Agrobacterium rhizogenes. Plant Cell, Tissue and Organ Culture. 15: 47-57.

Almahdy, A., Deddi, P.P., Ahsol, H. dan Mardinus. 2006. Skrining Tumbuhan Atraktif terhadap Lalat Buah Jantan Bactocera carambolae D \& H. Biota XI (3): 176-180.

Aryanti. 2001. Variasi Kandungan Artemisinin dari Akar rambut dan Regenerasi Artemisia cina Berg. Ex Poljakov sebagai Antikanker. Tesis. Program Pasca sarjana. Institut Pertanian Bogor. Bogor.

Baiza, A.M., Quiroz-Moreno, A., Ruiz, J.A. and LoyolaVargas, V.W. 1999. Genetic Stability of Hairy Root Culture Stramonium. Plant Cell, Tissue and Organ Culture. 59: 9-17.

Bayliss, M.W. 1980. Chromosome Variation in Plant Tissue in Culture. In: Vasil, I.K. (Eds). International Review of Cytology Supplement IIA: Perspectives in Plant Cell and Tissue Culture. Academic Press. New York. page. 133-144.

Bhojwani, S.S. and Razdan, M.K. 1983. Plant Tissue Culture: Theory and Practice. Elsevier Science Publishers. Netherlands.
Cowder, L.V. 1993. Genetika Tumbuhan. L. Kusdiarti (Penerjemah). Gadjah Mada University Press. Yogyakarta.

D'Amato, F. 1985. Cytogenetics of Plant Cell and Tissue Culture and Their Regenerates. CRC: Critical Review in Plant Sciences. 3: 73-122.

D’Amato, F. 1990. Somatic Nuclear Mutation In Vivo and In Vitro in Higher Plants. Caryologia. 43 (32): 191-204.

Dahlan, S. 1995. Mengenal Morus macroura Miq. Maskot Flora Sumatera Barat. Pross. Sem. Nas. Biologi XI. Ujung Pandang.

Darlington, C.D. and Wylie, A.D. 1945. Chromosome Atlas of Flowering Plants. George Allen and Unwin Ltd. Lodon.

De Vries- Uijtewaal, E., Gilissen, L.J.W., Flipse, E., Sree Ramulu, K. and De Groot, B. 1988. Characterization of Root Clones Obtained After Transformation of Monohaploid and Diploid Potato Genotypes with Hairy Root Inducing Strains of Agrobacterium. Plant Science.

Ermayanti, T.M. 1996. Biak Akar Hasil Transformasi antar Kotiledon Swainsona galegifolia dengan Agrobacterium rhizogenes untuk Produksi Swainsonin. Prosiding Seminar Bioteknologi II. Puslitbang Bioteknologi-LIPI Cibinong.

Ermayanti, T.M. 2003. Laporan Riset Unggulan Terpadu (RUT VIII). Pengembangan Kultur Tunas dan Kultur Akar Artemisia annua L. Penghasil Obat Antimalaria Artemisinin.

Ermayanti, T.M., Mc Comb, J.A. and O’Brien, P.A. 1993. Cytological Analysis of Seedling Roots, Transformed Root Cultures and Root Regenerates from Callus of Swainsona galegifolia (Andr) R.Br. J. of Experimental Botany. 44 (259): 375-380.

Flores, H.E. and Medina-Bolivar, F. 1995. Root Culture and Plant Natural Products: "Unearthing" The Hidden Half of Plant Metabolism. Feature Articles. Plant Tissue Culture and Biotechnology. 1 (2): 59-61.

Hakim, E.H., Achmad, S.A., Syah, Y.M., Ermayanti, T.M. dan Juliawaty, L.D. 2003. Ilmu Kimia dan Potensi Bioteknologi Tumbuhan Indonesia Sebagai Sumber Metabolit Sekunder. Abstrak No. SL1. Simposium Nasional Kimia Bahan Alam XIII. Himpunan Bahan Alam Indonesia dan Jurusan Kimia FMIPA Universitas Padjadjaran. Bandung. Tanggal 18-19 Februari 2003. Hal 269-279.

Hamill, J.D., Parr, A.J., Rhodes, M.J.C., Robins, R.J. and Walton, N.J. 1987. New Routes to Plant Secondary Products. Biotechnology. 5: 800804. 
Hendaryono, D.P.S. dan Wijayani, A. 1994. Teknik Kultur Jaringan: Pengenalan dan Petunjuk Perbanyakan Tanaman Secara Vegetatif Modern. Kanisius. Yogyakarta.

Jusuf, M. 2001. Genetika I. Struktur dan Ekspresi Gen. Institut Pertanian Bogor.

Karp, A. 1991. Cytological Techniques. Plant Cell Cultures Manual. C4: 1-13.

Mukherjee, S., Dha, S. and Jha, S. 1994. Chromosome Stability in Transformed Hairy Root Cultures of Artemisia annua L. Cell and Chromosome Research. $17: 71-76$.

Murashige, T. and Skoog, F. 1962. A Revised Medium for Rapid Growth and Bioassays with Tobacco Tissue Cultures. Physiologia Plantarum. 15: 473-497.

Nurdiani, F., Hakim, E.H., Syah, Y.M., Ermayanti, T.M., Achmad, S.A., Juliawaty, L.D. dan Makmur, L. 2003. Senyawa Adduct Diels Alder dari Akar Rambut Morus macroura Miq Hasil Transformasi Agrobacterium rhizogenes R1000. Abstrak No. CP48. Simposium Nasional Kimia Bahan Alam XIII. Himpunan Kimia Bahan Alam Indonesia dan Jurusan Kimia FMIPA Universitas Padjadjaran. Bandung. Tanggal 18-19 Februari 2003.

Petit, A., David, C., Dahl, G.A., Ellis, J.G., Guyon, P., Casse-Delbart, F. and Tempe, J. 1983. Further Extension of the Opine Concept: Plasmid in Agrobacterium rhizogenes Cooperate for Opine Degradation. Molecular General of Genetics. 190 : 204-214.

Prawitasari, T., Dorly dan Sri, W. 2005. Induksi Pembungaan Rambutan dengan Aplikasi Paklobutrazon. Biota X (2): $98-108$.

Ramsay, G. and Kumar, A. 1990. Transformation of Vicia faba Cotyledon and Stem Tissue by Agrobacterium rhizogenes: Infectivity and Cytological Studies. J. of Experimental Botany: 41 (228): 841-847.

Rhodes, M.J.C., Parr, A.J., Giuletti, A. and Aird, E.L.H. 1994. Influence of Exogenous Hormones on the Growth and Secondary Metabolite Formation in Transformed Root Cultures. Plant Cell Tissue \& Organ Culture. 29: 143151.

Soetjipto, H., Kristijanto, A.Ign. dan Asmorowati, R.S. 2007. Toksisitas Ekstrak Kasar Bunga dan Daun Ketepeng Cina (Senna alata L. Roxb.) terhadap Larva Udang Artemia salina Leach. Biota 12 (2): 78-82.

Sosef, M.S.M., Hong, L.T. and Prawirohatmodjo, S. 1998. Plant Resources of South- East Asia no 5 (3), Timber Tress: Lesser- Known Timbers. Back huys publishers, Leiden.
Subroto, M.A., Sudrajat, D., Djanakum, A. dan Widayat, E. 2000. Peningkatan Efisiensi Regenerasi Akar Rambut Solanum nigrum L. Melalui Induksi dengan Hormon Eksogen. Prosiding Seminar Hasil Penelitian dan Pengembangan Bioteknologi III.

Sudo, H., Yamakawa, T., Yamazaki, M., Aimi, N. and Saito, K. 2002. Bioreactor production of camptothecin by hairy root cultures of Ophiorrhiza pumila. Biotechnology Letters. 24: 359-363.

Sukanto, N.H., Achmad, S.A., Hakim, E.H., Syah, Y.M., Aimi, N., Kitajima, M. dan Takayama, H. 2001. Umbeliferon Senyawa Anti Fungal dari Tumbuhan Andalas Morus macroura. Bull. of The Indonesian Society of Natural Product Chemistry, 1: 13-14.

Suryo, H. 1995. Sitogenetika. Gadjah Mada University Press. Yogyakarta.

Suryo, H. 1998. Genetika. Gadjah Mada University Press. Yogyakarta.

Sutrian, Y. 1992. Pengantar Anatomi Tumbuhan: Tentang Sel dan Jaringan. PT. Rineka Cipta. Jakarta.

Towers, G.H.N. and Ellis, S. 1993. Secondary Metabolism in Plant Tissue Cultures Transformed with Agrobacterium tumefaciens and Agrobacterium rhizogenes In: Kinghorn, A.D. and Balardrin, M.F. (Eds.). Human Medical Agents from Plant American Chemical Society. Washington DC. pp. 56-78.

Van Wordragen, M.F., Ovuerkerk, P.P.F. and Dons, H.J.M. 1992. Agrobacterium rhizogenes Mediated Induction of Apparently Untransformed Root and Callus in Chrysantemum. Plan Cell, Tissue and Organ Culture. 26 : 149-157.

Welsh, J.R. dan Mogea, J.P. 1991. Dasar-dasar Genetika dan Pemuliaan Tanaman. S. Ekawati (Penerjemah). Erlangga, Jakarta.

Xu, Z., Jia, J.F. and Hu, Z. 1996. Enhancement by Osmotic Treatment of Hairy Root Transformation of Alfalfa Suspension Cultures and Chromosomal Variation in the Transformed Tissues. Australian J. of Plant Physiology. 24: 345-351.

Yatim, W. 1972. Genetika. Penerbit Tarsito. Bandung. 